Novianingsih Bethi, Irianto Djoko Pekik. The effect of training method and strength of the hands muscle towards float serve in volleyball extracurricular. Journal of Education, Health and Sport. 2019;9(2):30-43. eISNN 2391-8306. DOI http://dx.doi.org/10.5281/zenodo.2555533

http://ojs.ukw.edu.pl/index.php/johs/article/view/6554

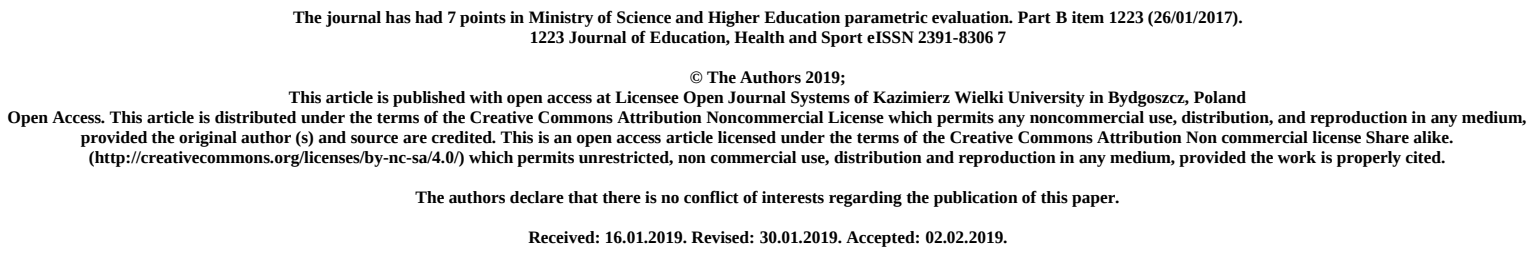

\title{
THE EFFECT OF TRAINING METHOD AND STRENGTH OF THE HANDS MUSCLE TOWARDS FLOAT SERVE IN VOLLEYBALL EXTRACURRICULAR
}

\author{
Bethi Novianingsih $^{1}$, Djoko Pekik Irianto
}

\begin{abstract}
Aim: The aim of the research is to find out: 1) the different of training method influence towards volley ball float serve skills on male students of volleyball extracurricular in Bantul 1 senior high school, Bantul 2 senior high school and Bambanglipuro 1 senior high school; 2) the different of strenght of the hands muscle influence towards volley ball float serve skill on male students of volleyball extracurricular in Bantul 1 senior high school, Bantul 2 senior high school and Bambanglipuro 1 senior high school; 3) Strenght of the hands muscle and training method interactions towards volleyball float serve skill on male students of volleyball extracurricular in Bantul 1 senior high school, Bantul 2 senior high school and Bambanglipuro 1 senior high school.

Methods: This research is an experimental research with 2x2 factorial designs, using pretest and posttest. Sample which used in this research is total of 40, divided into 2 groups of high and low depends on the test result from attributive variable (high group 20 and low group 20). Instrument measurement for strength of the muscle hands using pull and push dynamometer, with the score of validity of 0.63 and the score of reliability of 0.63 . Service float skill measurements using AAHPER serving accuracy test, with the test validity score of 0.920 and the score of reliability of 0.690 . Technique for data analysis used in this research is normality test using kolmogorov smirnov test, homogeneity test variant using levene's test and hypothesis research test using two way anova analysis.

Results: The result of the research is: 1) the result of two way anova analysis on training method obtained the $\mathrm{f}$ score of 4.381 with significance score of $0.043 ; 2$ ) the result of two way anova analysis on strength of muscle hands variable obtained F score of 9.038 with the significance score of 0.005 ; 3) the result of Two Way Anova analysis on interaction approach with hand eye coordination data obtained the F score of 13.625 with the significance score of 0.001 .

Conclusion: The conclution for this research is: 1) There is a significant influence from training method towards volley ball float serve skill on male students who join volleyball extracurricular in Bantul 1 senior high school,
\end{abstract}

1 Corresponding Author: Post Graduate Program, Sport Science, Universitas Negeri Yogyakarta, Indonesia, bethibowo@gmail.com ORCID ID: 0000-0001-7866-7217

2 Faculty of Sport Science, Universitas Negeri Yogyakarta, Indonesia, djoko.pekik@yahoo.com 
Bantul 2 senior high school and Bambanglipuro 1 senior high school; 2) There is a significant influence from strength of hands muscle towards volley ball float serve skill on male students who join volleyball extracurricular in Bantul 1 senior high school, Bantul 2 senior high school and Bambanglipuro 1 senior high school; 3) There is a significant interaction between training method and strenght of hands muscle towards volleyball float serve skill on male students who join volley ball extracurricular in Bantul 1 senior high school, Bantul 2 senior high school and Bambanglipuro 1 senior high school.

Keywords: training methods, hand muscle strength, service float skills

\section{INTRODUCTION}

Volleyball is one of the sports which popular with the community. Volleyball played by any circles whether it is old or young, man or woman, by amateur or professional. Ahmadi (2010: 20), said that volleyball games is one of the sports branch which is very popular after soccer and badminton. Popularity of volley ball can be seen from field facility existed in a village or town, also the held of competition and exhibition whether it is in local or national level.

Volleyball's popularity can be seen also in the high school students circle. This thing can be seen from the high interest from the students towards volley ball. NFHS Officials (2009: 3), stated "volleyball is popular both above and below the high school level". Apart from the volley ball that had been included in school curriculum which is in physical education, volley ball also developed by many schools through extracurricular activity for containing students who have interest and want to develop their skill in playing volleyball.

Volley ball including as a games that is not easy to be played with. In volley ball playing need a good coordination movement in order to do the basic movement of volley ball perfectly. Ahmadi (2010: 20), stated that volleyball games is the games which is very complex that is not very easy to be played by everybody because it is need very dependable movement coordination for doing all of the movements in volley ball.

Because of the complexity and the high difficulty in volleyball games, so in the coaching of the player needs a sufficient supporting factor. Danardono (2017: 3), stated that factor that influent the sport coaching succession is the availability of professional athlete, availability of professional coach, availability of facilities and sports equipment, a good training program and the sufficient budget and a test of health, physical and psychology measurements.

Based on the supporting factor above, one of the factors that have important role in sport coaching is the availability of good training program. Training program is a series of activities of exercise in a repetitive and programmed way to achieve certain goal (Rahayu, 2013: 123). The implementation of exercise program needs a training method for support the achievement of training objective.

Training method itself is a way that used for supporting the effectiveness of training program Rahayu (2013: 123), stated that training method is the whole ways or techniques in train, also how to treat the children in train within the training process. The trainer is required to be able to choose and determine the right training method according to training needs, so that it can support the development from children in train physically, technically and mentally.

Similarly in the volley ball training process, volley ball training program need to use the precise and suitable training method so the skill of player can be shaped optimally. Especially when practice basic skills in volleyball, because every basic technique have their own difficulties. Basic technique of the volleyball namely serve, passing, blocking, and smash 
(Ahmadi, 2010: 20). Every technique needs different training method because every technique has different movement characteristic and different difficulty level.

One of the techniques which are important to master by every volleyballs player is service. Service considered important because it is a start in a volleyball games. Other than that service also become a weapon for striking the opponent. Faruq (2009: 37), stated that "the serve is an offensive weapon meant to put opponent on their heels and slow down their offense". Serve is a weapon to attack the opponent to place the opponent into difficult position for doing counter attack.

One of the serve techniques that commonly used for attack is float serve. Float serve can be used as an offensive tool because the movement of the ball as result of float serves is difficult to be accepted by the opponent's player because the ball is not moving in a one track down and the speed of the ball is random (Ahmadi, 2010: 21). Float serves skill that can be mastered by the payer can be used as an offensive weapon.

Of course float serve skill is more difficult compared with upper serve and down serve, so that float serve skill must be trained with the precise method. In this research will review the use of massed practice and distributed practice training methods. Both those training methods have been widely used before for volleyball training and any other sport. Magill (2010: 399), said "massed and distributed practice trials provided for better learning skill”.

The main of massed practice training method is a training method that done continuously. Magill (2010: 399), said that "massed practice will have either no rest or very short rest interval between trials". In this training method usually the training section is shorter so it uses anaerob energy system more. Serve training which is done continually without any break can increase the ball serve movement pattern so that serve skill is getting better.

Distributed practice training method itself is a training method done by giving break rest in every training set. Magill (2010: 399), stated that "distributed practice is a practice schedule in which the amount of rest between practice sessions or trials is relatively long”. In this method there is a break in every training set, so the energy system used is aerob. Aerob system energy is very efficient and not causing too much exhaustion so that heart respiratory system can supply the oxygen to the entire body including muscle regularly so the movement performance is getting better (Iskandar, 2011: 43).

Several scientific researches have been done by expert about the use of massed practice and distributed practice training method to increase the sports performance. Research result from Murrray \& Udermann (2003: 21), concluding that "performance decreases under massed conditions of practice and increases under distributed conditions of practice". This research found is consistent with the research done by Alshumaimeri (2010: 14), it is stated that the distribution of practice effects has important implications on performance.

Another research conducted by Marwan (2010: 126), got the entire conclusion namely volleyball skill is increasing, on the students trained with distribution method it has been proven better that the students trained with intense training. Iskandar research (2011: 52), stated that basically both of the training methods namely massed practice and distributed practice can be used as a way to train, but from both of it in the reality distributed practice training is better in result to increase volleyball upper service skill. Based on that several researches shown that a precise method choosing can support the optimal formation of sports skills.

Besides training method, another factor that have important role in float serve skill is the strength of hands. Strength of hands muscle is the component that supports the realization serve movement. Faruq (2009: 28), stated that strength is the most important component in volleyball and one of which is needed for doing a serve. Hands muscle strength will support the muscle work in arms part so it can exert the energy maximally when doing a serve. 
Strength of hands muscle yields the hard and strong serve so that it will difficult for opponent to return the ball.

Result of the research from Priyanto (2014: 84), prove there is a strength of hands muscle endowment towards jumping serve skill on volleyball player. Research of Alim (2010: 20), concluded that the strength of hands have a role in serve skill. The existence of strong strength of muscle hands makes the serve is harder, faster and sharper so that it can be difficult for the opponents to reach.

The real phenomenon that the research found on the field is in Bantul 1 senior high school, Bantul 2 senior high school and Bambanglipuro 1 senior high school showed how high the interest of the students towards volleyball games. This can be seen from how many students that join volleyball extracurricular. Nevertheless, that high interest not yet accompanied by the ability to paly adequate volleyball. Many from the students are the new player who join the extracurricular because they wants to develop the skill to play volleyball and only slightly students that already have the talent and skill to play volleyball. Judging from the school sports achievement, it knows that from the 2012 to 2107 volleyball teams in Bantul 1 senior high school, Bantul 2 senior high school and Bambanglipuro 1 senior high school has never been won in any championship.

Judging from the observation result on the basic technique serve skill that is serve float skill it can be seen there are still so many students who are not able to execute float service properly. The result of observation on initial test float serve done by 21 students it is known that students can done float serve with average score of 1 . Many students also failed to do a float serve. Based on the observation result it is known that the students' problem when doing a float serve are the strength of hands which is not maximum, serve technique which is incorrect, ball placement that not maximum and also the less coordination of hands eye. Those problems become obstacle for the students to do afloat serve so that the serve result is less accurate.

The result of observation seen from coach factor through the interview, it is known that volleyball coach in Bantul 1 senior high school, Bantul 2 senior high school and Bambanglipuro 1 senior high school is a professional coach who has experient as a coach for 3 years. The coach has been implemented training methods to train the students. The coach widely use drill method for basic technique training, but the coach has not yet implementing special training method which is suitable for developing students' float serve skill. The obstacle that faced by the coach is the lack of technical mastery especially smash and serve technique. If the obstacle let loose without any fixing with increasing smash and serve tchniques skill, in result it can hamper the increase of volleyball sports achievement.

Judging by the physical supporting-capability that is students' hands strength is also unknown, because there is no measurement done before. Most coach is not consider necessary for doing a hands strength test, so that the real students' physical ability is unknown and give the same treatment towards the students who have high and low hands strength. This is certainly hampering the training process so that training method implemented by the coach become ineffective.

Based on the background description above, it is interesting to do a research about The Effect of Training Method and Strenght of the Muscles Hand Towards float serve in volleyball Extracurricular.

\section{MATERIAL \& METHODOLOGY}

\section{Types of Research}

This research is an experimental research with 2x2 factorial design, using Pretest and posttest. Factorial research has a purpose to see the main effect and interaction effect from 
independent variable toward dependent variable. The main effect is the direct effect of independent variable towards dependent variable; while interaction effect is a joint effect two or more independent variable towards dependent variable (Gozali, 2009: 62). Sometimes bot factors synergize each other towards response (positive), but sometimes the existence of one of the factors hamper the performance of the other factor (negative). The existences of those two mechanisms tend to increase the interaction effect between two factors.

For more detail of 2x2 factorial designs for this research can be seen on table below:

Tabel 1.2 x 2 Factorial Research Design

\begin{tabular}{ccc}
\hline \multirow{2}{*}{ Stregth of muscle hands } & \multicolumn{2}{c}{ Training method } \\
\cline { 2 - 3 } & Massed $\left(\mathrm{A}_{1}\right)$ & Distributed $\left(\mathrm{A}_{2}\right)$ \\
\hline High $\left(\mathrm{B}_{1}\right)$ & $\mathrm{A}_{1} \mathrm{~B}_{1}$ & $\mathrm{~A}_{2} \mathrm{~B}_{1}$ \\
\hline Low $\left(\mathrm{B}_{2}\right)$ & $\mathrm{A}_{1} \mathrm{~B}_{2}$ & $\mathrm{~A}_{2} \mathrm{~B}_{2}$ \\
\hline
\end{tabular}

Information:

$A_{1} B_{1}$ : Group which has high strength hands muscle given massed practice training.

$\mathrm{A}_{2} \mathrm{~B}_{1}$ : Group which has high strength hands muscle given distributed practice training.

$\mathrm{A}_{1} \mathrm{~B}_{2}$ : Group which has low strength hands muscle given massed practice training.

$\mathrm{A}_{2} \mathrm{~B}_{2}$ : Group which has low strength hands muscle given distributed practice training.

\section{Research subject}

Subject of this research is male students who join volleyball extracurricular in Bantul 1 senior high school, Bantul 2 senior high school and Bambanglipuro 1 senior high school. Research sample size counting is using formula from Slovin (Sujarweni, 2015: 16) can be seen below:

$$
n=\frac{N}{1+N e^{2}}
$$

Information:

$n$ : Sample Size

$\mathrm{N}$ : Population Size

$\mathrm{E}$ : Allowance for inaccuracy due to errors in samples obtained that can be tolerated $\{\mathrm{e}=0,1$ $(10 \%)\}$

$$
\begin{aligned}
& n=\frac{62}{1+\left(62(0,1)^{2}\right)} \\
& n=\frac{62}{1+0,62} \\
& n=\frac{62}{1.62} \\
& n=38,27 \quad \text { (Rounded become 40) }
\end{aligned}
$$

Based on the calculation above, minimum sample size used with $\alpha=0.1$ and degree of trust of $90 \%$ also the error level of $10 \%$ is 38, but for anticipating if in the research there is a sample who leave so there are a 2 samples as addition so that the total sample used in this research is 40. Next the sampling technique that use in this research is simple random sampling technique, which is a sample can be said random if every member of population have a same chance to be chosen as a sample. 
From the total of 40 sample used, it divided into two groups high-low based on the test result from attributive variable (20 high group and 20 low group). For the next in division to the sel done by using simple random sampling.

Table 2. Division of Four Group Samples

\begin{tabular}{ccc}
\hline \multirow{2}{*}{ Strength of Muscle Hands } & \multicolumn{2}{c}{ Training Method } \\
\cline { 2 - 3 } & Massed $\left(\mathrm{A}_{1}\right)$ & Distributed $\left(\mathrm{A}_{2}\right)$ \\
\hline High $\left(\mathrm{B}_{1}\right)$ & 10 & 10 \\
\hline Low $\left(\mathrm{B}_{2}\right)$ & 10 & 10 \\
\hline
\end{tabular}

\section{Instrumen and Data Collection Technique}

\section{Research instruments}

According to Arikunto (2010: 135), research instrument is a tool or facility that used by the researcher in data collection so that the job will be easier and the result will be better that is thorough, easy and sistematic so the data will be easily analyzed (Arikunto, 2010: 135). Data collecting in this research is using a test and measurement which is measurement towards strengh of muscle hands using pull and push dynamometer with validity score of 0.63 and the reliability score of 0.63 . measurement of float service skill using AAHPER Serving Accuracy Test with the validity test score of 0.920 and reliability score of 0.690 .

\section{Data Collection Technique}

Measurement data of float serve skill using AAHPER Serving Accuracy Test as follow (Richard, 1980: 102-104):

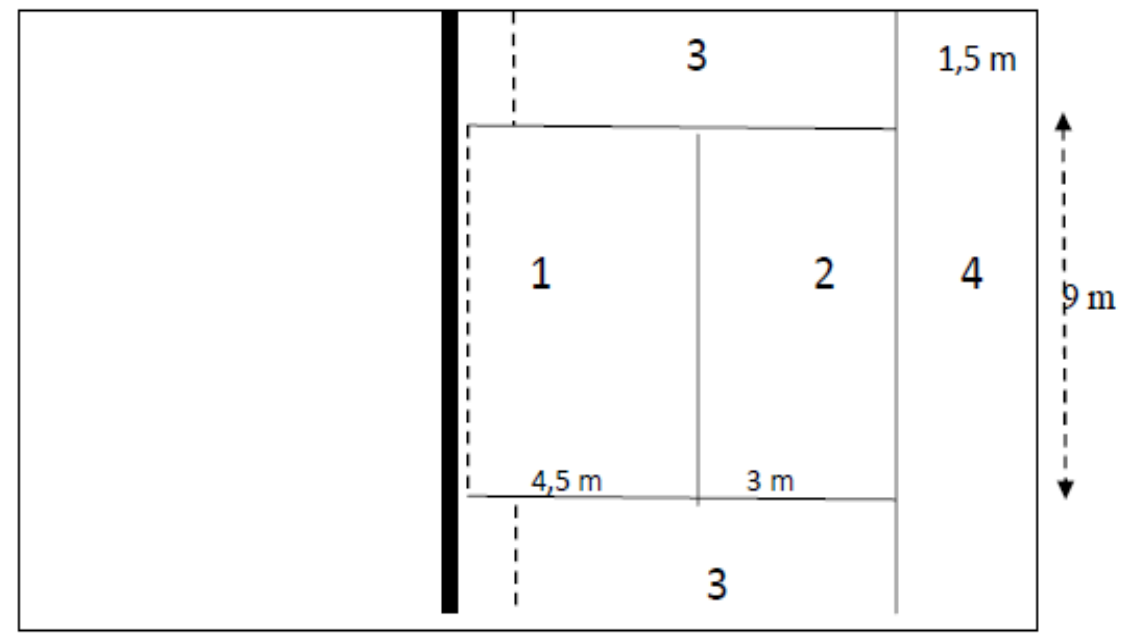

Picture 1. AAHPER Serving Accuracy Test

Source: (Richard, 1980: 103)

Procedure and steps of Float serve skill data collecting use AAHPER Serving Accuracy Test as follow:

a. Goal: doing a float serve skill measurement.

b. Equipment: ball, volleyball field net, stationary.

c. Scoring direction as follow:

1) Standing behind the field line

2) Volleyball field has been marked or square that every square given value of each.

3) Chances for doing service are 10 times.

4) Achieved score then add up as a final score. 
Measuremnt of the sterngh of muscle hands using pull and push dynamometer. The illustration picture of pull and push dynamometer from (Fenanlampir dan Faruq, 2015: 125) can be seen below :

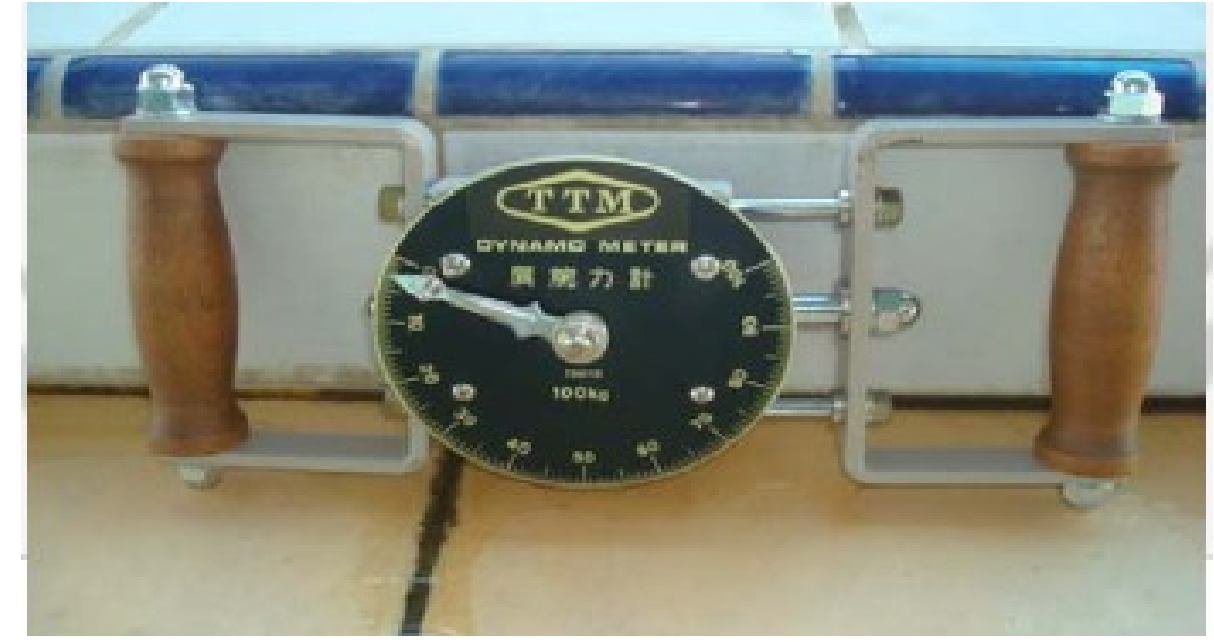

Picture 2. Pull And Push Dynamometer

Source: (Fenanlampir dan Faruq, 2015: 125)

Procedure of test according to (Ismaryanti, 2008: 116) as follow:

a. Goal: measureing the hands strength in pushing movement.

b. equimpment: pull and push dynamometer, alat tulis.Equipment: pull and push dynamometer, stationary.

c. Instruction of test:

1) Testee standing upright with both legs open as wide as shoulder.

2) Pull and push dynamometer held with both hands in front of the chest.

3) Body and the tool facing up the fronts.

4) Both upper hands to the side and the elbow bent.

5) Pull as strong as it could, both hands must not touch the chest.

Test taken twice and the best result will be taken.

\section{Data Analysis Technique}

Technique for analyzing the data that used in this research according to (Ghozali, 2014: 86) as follow:

1. Normality test to know whether the datahave distribution that normally distributed. Test that used is Kolmogorov Smirnov test.

2. Test homogeneity variant conducted to test the experiment group data variant similarity. Homogeneity test is using Levene's Test.

3. Two way anova analyses conducted to test the research hypothesis.

\section{RESULTS and DISCUSSION}

\section{Results}

1. Results of normality and homogeneity test

Normality test and homogeneity test is a pre requirement test before doing hypothesis test. Normality data test can be done using Kologorov Smirnov test. Homogeneity test using levene's test.

\section{a. Normality Test}

Normality test has been conducted to know whether the analyzed variable have the distribution that normally distributed or not. Normality data test done using Kolmogorov Smirnov (KSZ). Data result reading said it is normal if $p$ value (Sig.) $>0,05$. The result of normality test shown in the table below 
Tabele 3. The Result of Normality Research Data test

\begin{tabular}{llrrr}
\hline \multirow{1}{*}{ Group } & Float Serve Skill & Statistic & Sig. & \multirow{2}{*}{ Ket. } \\
\hline High strength & Pretest & 0,599 & 0,865 & Normal \\
\cline { 2 - 5 } massed- Method & Posttest & 0,600 & 0,864 & Normal \\
\hline High strength & Pretest & 0,457 & 0,985 & Normal \\
\cline { 2 - 5 } distributed- method & Posttest & 0,459 & 0,984 & Normal \\
\hline $\begin{array}{l}\text { Low Strength } \\
\text { massed-Method }\end{array}$ & Pretest & 0,387 & 0,998 & Normal \\
\cline { 2 - 5 } $\begin{array}{l}\text { Low Strength } \\
\text { distributed-Method }\end{array}$ & Posttest & 0,475 & 0,978 & Normal \\
\cline { 2 - 5 } & Pretest & 0,544 & 0,929 & Normal \\
\hline
\end{tabular}

Source: Primary data analyzed in 2018

Table above showing the result of the normality data calculation from the group with high strength massed practice training method when pretest got KSZ score of 0.599 with the significance score of 0.864 . The result of the normality data calculation from the group with high strength distributed practice training method when pretest got the KSZ score of 0.457 with significance level of 0.985 , when posttest the result got for KSZ score is 0.459 with significance level of 0.984 .

The result of normality test on low strength massed practice training method group when pretest got the KSZ score of 0.387 with the significance level of 0.988 , when posttest got the KSZ score of 0.475 with the significance score of 0.987 . The result of normality test calculation on the low strength distributed practice training method groups when pretest got the KSZ score of 0.544 with significance score of 0.929 , when posttest the KSZ score is 0.841 with the significance score of 0.480

Because of the result of normality test analysis on the data pretest and posttest every treatment group got the significance score more than $0,05(p>0,05)$, so it can be said that data of this research is normally distributed. It means that this data distribution meets the criteria of normality curve as a requirement of parametric statistical analysis.

\section{b. Homogeneity Test Result}

Homogeneity test is use to test the variant similarity between data on the treatment groups. Statistical test that used for testing the homogeneity variant is F-test, which is comparing the biggest variant with the smallest variant. The result of the homogeneity test shown on the table below

Table 4. The Result of Homogeneity Pretest Data.

\begin{tabular}{|c|c|c|c|c|}
\hline Data & Gruop & F Calculation & Sig. & Ket. \\
\hline \multirow{4}{*}{ Data } & High strength massed- Method & \multirow{4}{*}{1,447} & \multirow{4}{*}{0,246} & \multirow{4}{*}{ Homogeneous } \\
\hline & $\begin{array}{l}\text { High strength distributed- } \\
\text { method }\end{array}$ & & & \\
\hline & Low Strength massed-Method & & & \\
\hline & Low strength distributed Method & & & \\
\hline
\end{tabular}

Based on the homogeneity data pretest result it obtains the F calculation of 1.447 with the significance score of 0.245 . Because of the analysis result got the significance level bigger than $0.05(p>0,05)$, so it can be said that pretest data result of volleyball float serve skill in every treatment group are homogeneous. It means that there is a variant similarity between data pretest of four groups treatment so the data meet the requirement of the homogeneity for parametric analysis. 
Table 5. The Result of Homogeneity posttest Data

\begin{tabular}{clllll}
\hline Data & \multicolumn{1}{c}{ Kelompok } & F hitung & Sig. & Ket. \\
\cline { 1 - 2 } Data & High strength massed- Method & & & \\
\cline { 2 - 2 } & $\begin{array}{l}\text { High strength distributed- } \\
\text { method }\end{array}$ & & & \\
\cline { 2 - 2 } & Low Strength massed-Method & & 0,095 & Homogeneous \\
\cline { 2 - 2 } & $\begin{array}{l}\text { Low strength distributed } \\
\text { Method }\end{array}$ & & & \\
\hline
\end{tabular}

Source: Primary data analyzed in 2018

Based on the homogeneity data posttest result it obtains the F calculation of 2.285 with the significance score of 0.095 . Because of the analysis result got the significance level bigger than $0.05(p>0,05)$, so it can be said that pretest data result of volleyball float serve skill in every treatment group are homogeneous. It means that there is a variant similarity between data pretest of four groups treatment so the data meet the requirement of the homogeneity for parametric analysis.

\section{Results of hypothesis test}

This research proposes 3 researches hypothesis. Hypothesis test in this research is using Two Way Anova test. The result of data analysis for hypothesis test as follow

Table 6. Analysis result of Two Way Anova

\begin{tabular}{|c|c|c|c|c|c|}
\hline Treatment & Group & Mean & $\begin{array}{c}\mathbf{F} \\
\text { calculation }\end{array}$ & Sig. & Ket. \\
\hline \multirow{2}{*}{ Training method } & Massed & 22,50 & \multirow{2}{*}{4,381} & \multirow{2}{*}{0,043} & \multirow{2}{*}{ Significant } \\
\hline & Distributed & 25,25 & & & \\
\hline \multirow{2}{*}{$\begin{array}{l}\text { Strength of muscle } \\
\text { hands }\end{array}$} & High & 25,85 & \multirow{2}{*}{9,038} & \multirow{2}{*}{0,005} & \multirow{2}{*}{ Significant } \\
\hline & Low & 21,90 & & & \\
\hline $\begin{array}{l}\text { Training Method } \\
\text { interaction* Strength of } \\
\text { muscle hands }\end{array}$ & & & 13,625 & 0,001 & Significant \\
\hline
\end{tabular}

Source: Primary data analyzed in 2018

\section{a. Test of Hypothesis 1}

Hypothesis 1 that proposes in this research is "there is an effect of training method towards volleyball float serve skill on the male students who join volleyball extracurricular in Bantul 1 senior high school, Bantul 2 senior high school and Bambanglipuro 1 senior high school”. Based on the Two Way Anova analysis result on the training method variable got the $\mathrm{f}$ calculation score of 4.381 with the significance level of 0.043 . Because of the significance score of 0.043 is smaller than $0.05(p<0,05)$, it can be concluded that there is significant effect from training method towards volleyball float serve skill on the male students who join volleyball extracurricular in Bantul 1 senior high school, Bantul 2 senior high school and Bambanglipuro 1 senior high school, so that the hypothesis is accepted.

\section{b. Test of Hypothesis 2}

Hypothesis 2 in this research is "there is effect form strength of muscle hands towards volleyball float serve skill on the male students who join volleyball extracurricular in Bantul 1 senior high school, Bantul 2 senior high school and Bambanglipuro 1 senior high school”. Based on the Two Way Anova analysis result on the strength of muscle hands variable got the $\mathrm{f}$ calculation score of 9.038 with the significance level of 0.043 . Because of the significance score of 0.005 is smaller than $0.05(p<0,05)$, it can be concluded that there is significant effect 
from strength of muscle hands towards volleyball float serve skill on the male students who join volleyball extracurricular in Bantul 1 senior high school, Bantul 2 senior high school and Bambanglipuro 1 senior high school, so that the hypothesis is accepted.

\section{c. Test of Hypothesis 3}

Hypothesis 3 in this research sounds "There is interaction between Training method and strength of muscle hands towards volleyball float serve skill on the male students who join volleyball extracurricular in Bantul 1 senior high school, Bantul 2 senior high school and Bambanglipuro 1 senior high school”. Based on the Two Way Anova analysis result on the interaction approach data with the hand eye coordination got the f calculation score of 13.626 with the significance level of 0.001 . Because of the significance score of 0.001 is smaller than $0.05(p<0,05)$, it can be concluded that there is significant effect between training method and strength of muscle hands towards volleyball float serve skill on the male students who join volleyball extracurricular in Bantul 1 senior high school, Bantul 2 senior high school and Bambanglipuro 1 senior high school, so that the hypothesis is accepted.

Interaction between training method and strength of muscle hands towards volleyball float serve skill can be seen in the following graphic:

Estimated Marginal Maans of Posttest

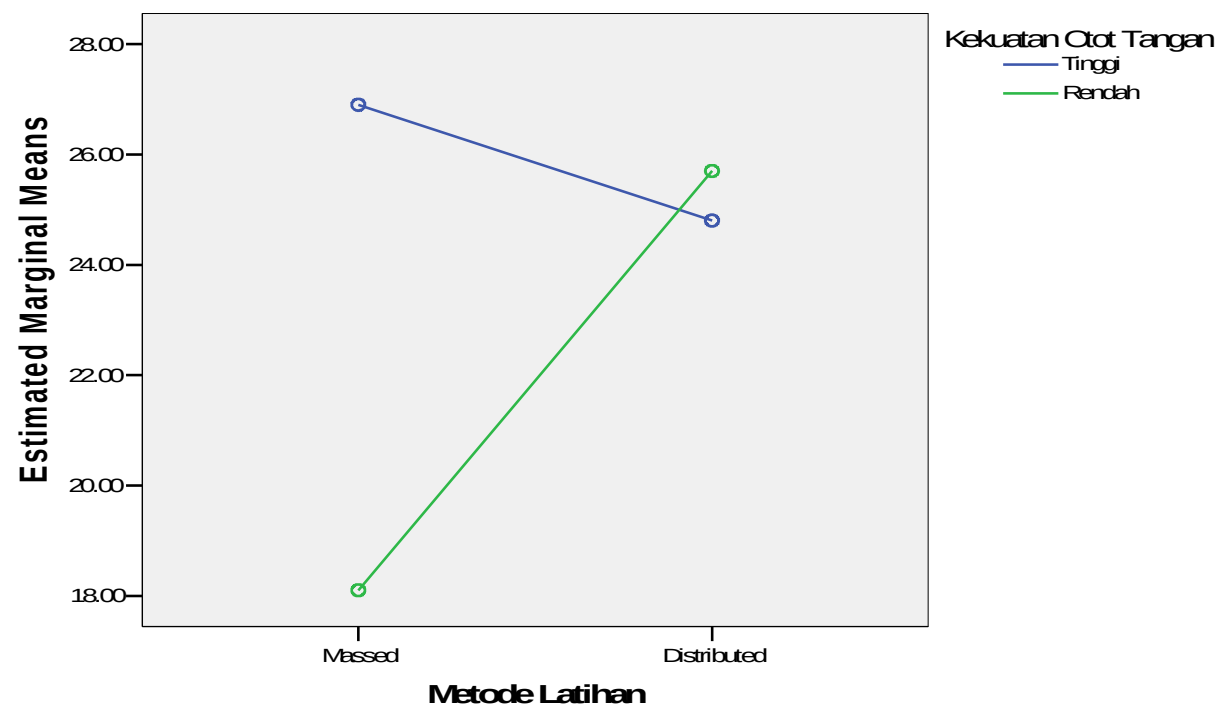

Picture 3. Interaction of Training Method and Strength of Muscle Hands

Based on the graphic it is known that there is interaction between training method and the strength of muscle hands. Interaction shown with the intersection of line on the garphic above whic means training method and the strength of muscle hands gives influence towards volleyball float serve skill. The right combination between training method and the strength of muscle hands will result in maximum volleyball float serve skill.

\section{Discussion}

1. The effect of training method towards volleyball float serve skill on the male students who join volleyball extracurricular in Bantul 1 senior high school, Bantul 2 senior high school and Bambanglipuro 1 senior high school

The result of research data analysis has proven there is an influence of training method towards volleyball float serve skill on the male students who join volleyball extracurricular in Bantul 1 senior high school, Bantul 2 senior high school and Bambanglipuro 1 senior high school $(p=0,043)$. Distributed practice training method is better in increasing the float serve skill on the male students. Distribution practice itself is one of the trainings that interspersed 
with a break between training sections. According to Aghdasi and Jourkesh (2011: 102), distributed practice setting certain days to rest or no practice with duration of rest more than duration of practice. Distributed practice compiled with giving the rest for several days or not giving train between training sections with the break duration is longer than the training duration.

Distributed practice training method is better in increasing the float serve skill on the male students because in this training method compiled with the time for break. Break time given in every training season giving the time for the students for recovery. Recovery process makes students didn't experience too much exhaustion so that the students can so the training until the end. The result that achieved is the optimum enhancement of volleyball float serve skill. Supported by the opinion from Alshumaimeri (2010: 15), it is stated among the advantage of distributed practice is there is a chance for break so that it will experience too much exhaustion.

Time-giving for break in the Distributed practice also have a benefits for the students to do a relaxation. Break time interval between training sections can be utilized by the students for energy recovery so that the students will be ready for the next training section. Students' physical and power that is already recovered after the break will show the optimum performance. The result is can achieve the better skill enhancements. Corresponding with the opinion form Rahayu (2016: 125), stated that the main purpose of break time is for recovery between training so that will be no too much exhaustion.

Distributed practice training method also has benefit with the shape of chance for the coach to do a correction and evaluation in every movement of float serve done by the students. Every wrong movement can be directly evaluated and justified by the coach, so that the students' mastery towards basic move of float serve will be better. Supported by opinion of Rahayu (2016: 125), stated that break time also give the chance for the coach for doing a correction of movement mistake done by the children train and then give a chance for children train to fix the mistake so that Float serve skill will be optimized.

\section{The effect of the strength of hands muscle towards volleyball float serve skill on the male students who join volleyball extracurricular in Bantul 1 senior high school, Bantul 2 senior high school and Bambanglipuro 1 senior high school}

The result of research data analysis proven that there is an influence form the strength of muscle hands towards volleyball float serve skill on the male students who join volleyball extracurricular in Bantul 1 senior high school, Bantul 2 senior high school and Bambanglipuro 1 senior high school $(p=0,005)$. It means that volleyball float serve skill need a high strength of hands muscle.

Strength of the hands muscle is the most important component that would be needed in volley ball games. According to Sukadiyanto (2010: 131), stated that strength is a muscle or a group of muscles' ability to overcome the weight and resistance. Strength of hands muscle is really needed to support the movement activity in volleyball games and one of it is needed when doing a float serve

The high strength of the hands muscle can produce the better float serve skill because when doing float serves, strength of hands muscle is a main asset for doing float serves movement. Strength of the hands muscles would be needed by the students when executing serve, where the high strength of hands muscle will result in a strong and hard ball punch so that it will be on target. Faruq (2009: 28), stated strength of hands muscle can produce hard and strong serves.

The main basic movement of floating service is when hitting the ball in flight. The strength of the hands muscle have a role when the student executing a serve. How strong muscle strength owned by the students will determine the line of ball punch. The higher hands muscle strength the faster and stronger the ball rushed to the target. Faruq (2009: 28), stated 
that the role of the strength of the hands muscles towards succession of service is the strong hands muscle will produce the strong, hard, and sharp.

The strength of the hands muscle would be needed by the students so that they are capable of doing float serve precisely and will hit the target. Float serve including as the kind of serve which is difficult to be done especially for the beginner, so that the students must have the strong basic skill which is strength of the hands muscle that can support when doing a hitting ball movement. Faruq (2009: 28), stated that the strength of the hands muscle would be needed when hit so it will produce hard ball punch and hit the target.

3. Interaction between training method and the strength of the hands muscle towards volleyball float serve skill on the male students who join volleyball extracurricular in Bantul 1 senior high school, Bantul 2 senior high school and Bambanglipuro 1 senior high school

The result prove that there is an interaction between training method and the strength of hands musle towards volleyball float serve skill on the male students who join volleyball extracurricular in Bantul 1 senior high school, Bantul 2 senior high school and Bambanglipuro 1 senior high school Bambanglipuro $(p=0,001)$.

Float serve is one of the serves kind that difficult to execute, so that in the training process it need a skill to choose the precise training method and it also important with the determination of the strength of hands muscle of the students. Strength of the hands muscle become the main factors to be determined in taking the training method, because the main strength muscle is the basic asset for doing a float serve. Training method choosing which is suitable with student's strength of the hands muscle will increase the float seve skill efficiently.

Based on the analysis result the enhancement of volleyball float serves skill on the groups that given training using massed practice that is the group with using high strength of hands muscle massed practice training method is 7.50 while the enhancements from the group with using low strength hands muscle massed practice training method is 1.20 . This result showed that there is an interaction in the implementation of massed practice training method with the high strength of hands muscle so that the optimum result can be achieved.

The highest enhancement of volleyball float serves skill is happening in the group which is trained by using the massed practice with the high strength of hands muscle can be explained because float serves skill need a basic asset which is high strength of hands muscle. Students with high strength of hands muscle will execute serve easily compared with the students who have low strength of hands muscle. High strength of hands muscle owned by the students will make them easier to execute the better float serve.

The high strength of hands muscle combined with massed practice training method, where the train done without any break. This method is suitable for the students who already have the basic asset that is the high strength of the hands muscle, so that continuous training will increase the movement pattern and the mastery level of float serve skill will be better. As said by Hairy (1999) in Suteja (2009: 38), stated movement training using repetition with as frequent as possible can enhance the quality of movement pattern and the mastery level will be better.

The implementation of massed practice training method for the students who have high strength of hands muscle will make the float service skill increase more because it is done repetitively and continuously and with as many frequency as possible. Main asset which is high strength of the hands muscle become the support of movement mastery that keeps getting better so that the float serve skill increase optimally. Supported by the opinion of Alshumaimeri (2010: 15), stated that massed practice training method gives the opportunity to do a training repetition as many as possible so it can enhance the mastery significantly. 


\section{CONCLUSION}

Based on the data analysis and the discussion that has been done, the conclusion for this research is as follow:

1. There is a significant influence from training method towards volley ball float serve skill on male students who join volleyball extracurricular in Bantul 1 senior high school, Bantul 2 senior high school and Bambanglipuro 1 senior high school. Distributed practice training method is better if it is compared by the massed practice in volleyball float serve training.

2. There is a significant influence from strength of hands muscle towards volley ball float serve skill on male students who join volleyball extracurricular in Bantul 1 senior high school, Bantul 2 senior high school and Bambanglipuro 1 senior high school. Students who have high strength of hands muscle is better rather than the students who have low strength of hands muscle.

1. There is an interaction between training method and strenght of hands muscle towards volleyball float serve skill on male students who join volley ball extracurricular in Bantul 1 senior high school, Bantul 2 senior high school and Bambanglipuro 1 senior high school. It means that if training method combined with the students strength of hands muscle precisely will capable of increasing volleyball Float serve optimally. Based on the research result it is known that the interaction between massed practice training method and the strenght of hands muscle produce better volleyball float serve mastery.

\section{REFERENCES}

Ahmadi, N. (2010). Panduan olahraga bola voli. Solo: Era Pustaka Utama.

Alshumaimeri, Y. (2010). Massed vs distributed practice. Journal of research quarterly for exercise and sport, 59 (4), 1-15.

Arikunto, S. (2010). Prosedur penelitian suatu pendekatan praktek. Jakarta: Rineka Cipta.

Danardono. (2017). Pembinaan altet. Yogyakarta: FIK UNY.

Faruq, M. M. (2010). Meningkatkan kebugaran jasmani melalui permainan dan olahraga bola voli. Jakarta: Grasindo.

Fenanlampir, A., \& Faruq, M. M. (2015). Tes dan pengukuran dalam olahraga. Yogyakarta: Andi Offset.

Ghozali, I. (2014). Analisis multivariate dengan aplikasi SPSS. Semarang: UNDIP.

Iskandar, M., I. (2011). Perbedaan pengarus massed practice dengan distributed practice terhadap kemampuan pass bola atas bola voli yunior Klub Bola Voli Rinex Boyolali. Jurnal Ilmiah SPIRIT, 11 (1), 47-55.

Ismaryati. (2008). Tes dan pengukuran olahraga. Surakarta: UNS Press.

Magill, R., A. (2010). Motor learning and control concepts and applications. New York USA: McGraw-Hill.

Marwan, I. (2009). Pengaruh metode latihan distribusi, latihan padat dan motivasi berprestasi terhadap keterampilan bola voli. Jurnal Forum Kependidikan, 28 (2), 119-126.

Murray, S., \& Udermann, B. E. (2003). Massed vs distributed practice: which is better?, Cahperd journal, 28 (1), 19-22.

NFHS Officials. (2009). Officiating volleyball. USA: Human Kinetics.

Priyanto, E. (2014). Sumbangan power tungkai, power lengan, kekuatan otot perut, kekuatan otot punggung dengan kemampuan melakukan servis jumping pada atlet bolavoli (Master’s Thesis). Universitas Negeri Yogyakarta, Yogyakarta, Indonesia. 
Rahayu, E., T. (2013). Strategi pembelajaran pendidikan jasmani. Bandung: Alfabeta.

Rahyubi, H. (2016). Teori-teori belajar dan aplikasi pembelajaran motorik deskripsi dan tinjauan kritis. Jawa Barat: Referens.

Sujarweni, W. (2015). SPSS untuk Penelitian. Yogyakarta: Pustaka Baru Press.

Sukadiyanto. (2010). Pengantar teori dan metodologi melatih fisik. Yogyakarta: FIK UNY.

Suteja. (2009). Pengaruh metode latihan dan koordinasi mata kaki terhadap keterampilan bermain sepakbola (Master's Thesis). Universitas Negeri Surakarta, Surakarta, Indonesia.

Weite, P. (2009). Aggressive Volleyball. USA: Human Kinetics. 